\title{
Pituitary adenylate cyclase-activating polypeptide attenuates tumor necrosis factor- $\alpha$-induced apoptosis in endothelial colony-forming cells
}

\author{
NING BIAN ${ }^{1 *}$, GANG DU ${ }^{1 *}$, MAN FAI IP ${ }^{1,2}$, JUAN DING $^{3}$, QING CHANG $^{4}$ and ZICHENG LI $^{1}$ \\ ${ }^{1}$ Department of Cardiology, The First Affiliated Hospital of Jinan University, Guangzhou, Guangdong 510630; \\ ${ }^{2}$ Department of Cardiology, Macau Kernel Earl General Hospital, Macau 820200; ${ }^{3}$ Department of Cardiology, North Branch, \\ People's Hospital of Xinjiang Uygur Autonomous Region, Ürümqi, Xinjiang Uyghur Autonomous Region 830054; \\ ${ }^{4}$ Department of Histology and Embryology, Medical College of Jinan University, Guangzhou, Guangdong 510632, P.R. China
}

Received September 23, 2016; Accepted December 20, 2016

DOI: 10.3892/br.2017.917

\begin{abstract}
Endothelial colony-forming cells (ECFCs) are important in angiogenesis and vascular proliferation. Tumor necrosis factor (TNF)- $\alpha$ is a significant risk factor for the development of atherosclerosis and a key proinflammatory cytokine known to induce apoptosis in endothelial cells. Pituitary adenylate cyclase-activating polypeptide (PACAP) is one of the members of the vasoactive intestinal peptide/secretin/growth hormone-releasing hormone/glucagon superfamily and exists in two biological active forms, PACAP 38 and PACAP 27. PACAP has been reported to help prevent endothelial apoptosis via an anti-inflammatory mechanism. However, to the best of our knowledge, the anti-apoptotic potential of PACAP has not been investigated in ECFCs. The aim of the present study was to demonstrate the efficacy of PACAP for decreasing TNF- $\alpha$-induced apoptosis in ECFCs. The results indicated that PACAP exerts a cytoprotective effect on ECFCs exposed to TNF- $\alpha$. Furthermore, PACAP partially rescues the proliferation potential of ECFCs inhibited by prolonged TNF- $\alpha$ exposure. These findings support an anti-inflammatory role for PACAP in circulation diseases.
\end{abstract}

\section{Introduction}

Endothelial progenitor cells (EPCs) have been demonstrated as important in neovascularisation and contribute to vascular

Correspondence to: Professor Zicheng Li, Department of Cardiology, The First Affiliated Hospital of Jinan University, 613 Huangpu Road, Guangzhou, Guangdong 510630, P.R. China E-mail: zichengli@163.net

\section{${ }^{*}$ Contributed equally}

Key words: endothelial colony-forming cells, tumor necrosis factor- $\alpha$, pituitary adenylate cyclase-activating polypeptide, apoptosis repair (1). Endothelial colony-forming cells (ECFCs) are a subset of EPCs, also referred to as late-outgrowth EPCs, which exhibit essential progenitor characteristics, including high proliferative potential and the capacity for self-renewal. ECFCs have received widespread attention as the primary progenitor population contributing to neovasculogenesis, in particular due to their reparative capacity to ameliorate vascular injury (2,3). Reduced numbers and altered function of ECFCs are associated with endothelial dysfunction under disease conditions, such as diabetic hyperglycemia and arterial hypertension (4-6). Furthermore, endothelial dysfunction is an early abnormality in the process that leads to atherosclerosis and its associated complications (7). Currently, the transfer of ECFCs is considered to be a therapeutic modality that is potentially effective in ischemia-associated conditions, such as myocardial infarction (8) and in non-ischemic inflammatory models, such as dilated cardiomyopathy (9). ECFC levels have been shown to be negatively correlated with risk factors for atherosclerosis (10), suggesting that decreased repair of vascular plaques may be the result of ECFC depletion or insufficient production (11). Repair of a damaged endothelium by ECFCs is likely critical in preventing or limiting blood vessel injury (12-14).

Evidence from in vitro and clinical studies indicates that inflammation and oxidative stress triggers ECFC apoptosis. Atherosclerosis develops through an inflammatory pathology, which results in plaque formation and acute coronary events. Tumor necrosis factor (TNF)- $\alpha$ is a proinflammatory cytokine that is central in the pathogenesis of atherosclerosis $(15,16)$ and a contributing risk factor in metabolic disorders, such as insulin resistance and dyslipidemia. Primarily produced by activated macrophages (17), TNF- $\alpha$ regulates numerous immune cell functions, including rolling, adhesion, proliferation and apoptosis (18). Additionally, TNF- $\alpha$ is key as an inflammatory mediator and as an inducer of apoptosis in endothelial cells and ECFCs.

Pituitary adenylate cyclase-activating polypeptide (PACAP), encoded by the ADCYAPl gene, was originally isolated from an ovine hypothalamus extract (19), and has been identified in gastrointestinal, respiratory, cardiovascular 
and urogenital systems $(20,21)$. PACAP is one of the members of the vasoactive intestinal peptide/secretin/growth hormone-releasing hormone/glucagon superfamily and exists in two biological active forms, PACAP 38 and PACAP 27, with three currently identified receptors: PAC1, VPAC1 and VPAC2. PACAP has been reported to promote survival in various types of cell, including lymphocytes, chondrocytes, endothelial cells and Schwann cells, as well as in liver, lung, and ovarian tissue samples $(22,23)$. Adcyap1-deficient mice exhibited a markedly higher degree of, as well as more wide spread, inflammation (24), increased levels of proinflammatory cytokines, such as interleukin (IL)-6, TNF- $\alpha$, interferon (IFN)- $\gamma$ and decreased levels of IL-4 (25). Due to its broad distribution in tissues and its cytoprotective effects on many cell types, PACAP is considered to be an attractive therapeutic candidate possessing anti-inflammatory and anti-atherosclerotic potential.

\section{Materials and methods}

Materials. TNF- $\alpha$ was obtained from PeproTech, Inc. (Rocky Hill, NJ, USA). 3-(4,5-Dimethylthiazol-2-yl)-2,5 diphenyltetrazolium bromide (MTT) was purchased from Sigma-Aldrich (Merck KGaA, Darmstadt, Germany). Synthetic PACAP38 was obtained from GL Biochem (Shanghai) Ltd. (Shanghai, China). Cluster of differentiation CD34 (dilution, 1:200; cat. no. 561440), CD31 (dilution, 1:200; cat. no. 562861) and KDR (dilution, 1:400; cat. no. 560494) antibodies were obtained from BD Biosciences (San Jose, CA, USA). The secondary antibody (goat anti-rabbit HRP-IgG; cat. no. sc-2048) was purchased from Santa Cruz Biotechnology, Inc. (Dallas, TX, USA). The FITC Annexin V Apoptosis Detection kit was purchased from BD Pharmingen (San Diego, CA, USA) and endothelial differentiation medium (EGM-2MV) was obtained from Clonetics Corp. (San Diego, CA, USA). Lymphoprep ${ }^{\mathrm{TM}}$ was obtained from Axis-shield (Oslo, Norway). The human umbilical cord blood (UCB) was obtained from six patients of the First Affiliated Hospital of Jinan University (Guangzhou, China) between May 2014 to January 2015. Patients with known genetic diseases, cancer, a history of anemia, or medical conditions that involved cardiopulmonary insufficiency, were excluded. All subjects provided written informed consent and the present study was approved by the Regional Ethics Committee of Jinan University.

Cell culture. ECFCs derived from human UCB were isolated by Lymphoprep ${ }^{\mathrm{TM}}$ density gradient centrifugation at $800 \mathrm{x} \mathrm{g}$ for $20 \mathrm{~min}$ at $4^{\circ} \mathrm{C}$. Following centrifugation, the mononuclear cell (MNC) layer was harvested and washed twice with $0.9 \%$ saline. The MNCs were cultured at $37^{\circ} \mathrm{C}$ in $5 \% \mathrm{CO}_{2}$ in endothelial differentiation medium (EGM-2MV) containing 5\% fetal bovine serum, vascular endothelial growth factor, fibroblast growth factor-2, epidermal growth factor and insulin-like growth factor-1. Approximately two days after the initial plating, non-adherent cells were discarded and fresh medium was applied; thereafter, the medium was replaced on alternating days. Subsequent to 1-2 weeks of culture, the cells exhibited a paving stone-like morphology and were identified as ECFCs by immunohistochemical staining. In order to evaluate the effect of TNF- $\alpha$ on ECFCs, ECFCs were treated with TNF- $\alpha$ (10, 20 and $40 \mathrm{ng} / \mathrm{ml})$ for $24 \mathrm{~h}$ and the cleaved caspase-3 expression level was determined by western blot analysis. Subsequently, flow cytometric apoptosis assays were performed on the control group (cells were cultured in EGM-2MV), the TNF- $\alpha$ group (cells were cultured in EGM-2MV, pulsed with $20 \mathrm{ng} / \mathrm{ml}$ TNF- $\alpha$ ) and 3 PACAP groups [the ECFCs were treated with $20 \mathrm{ng} / \mathrm{ml} \mathrm{TNF-} \alpha$ for 5 min and the medium was replaced with fresh medium, which contained PACAP (1, 10 and $100 \mathrm{nM})]$. The MTT assay and flow cytometry were performed to evaluate cell proliferation and cell cycle.

ECFC immunohistochemistry. ECFCs were fixed with 4\% paraformaldehyde for $15 \mathrm{~min}$ and permeabilized with $0.5 \%$ Triton X-100 in phosphate-buffered saline (PBS) buffer $(0.1 \mathrm{mmol} / \mathrm{l})$ for $20 \mathrm{~min}$. After blocking with $10 \%$ goat serum for $20 \mathrm{~min}$, cells were incubated with anti-CD31 (1:200), -CD34 (1:200), or -KDR (1:400) antibodies overnight at $4^{\circ} \mathrm{C}$. Cells were washed three times with PBS, which was followed by application of the goat anti-rabbit IgG secondary antibody (1:500) with an avidin-peroxidase conjugate. Visualization was performed using a DAB chromogen kit (cat. no. ST033; Beyotime Institute of Biotechnology, Shanghai, China) and images were obtained by bright-field microscopy (IX71; Olympus Corporation, Tokyo, Japan).

Western blot analysis. ECFCs were homogenized in PBS containing a protease inhibitor cocktail $(50 \mathrm{mM}$ Tris, $\mathrm{pH}$ 7.6, $150 \mathrm{mM} \mathrm{NaCl}, 1 \mathrm{mM}$ EDTA, $1 \%$ Triton X-100, 0.5\% sodium deoxycholate, $0.1 \%$ SDS and $10 \%$ glycerol). Samples were separated by $10 \%$ SDS-PAGE and then transferred to nitrocellulose membranes (Bio-Rad Laboratories, Inc., Hercules, CA, USA) at $30 \mathrm{~V}$ for $20 \mathrm{~min}$. The membranes were blocked with $5 \%$ bovine serum albumin $(\mathrm{w} / \mathrm{v})$ at room temperature for $1 \mathrm{~h}$, and incubated with primary anti-cleaved caspase 3 antibody (1:1,000; Abcam, Cambridge, MA, USA; cat. no. ab-2302) at $4^{\circ} \mathrm{C}$ overnight, and then incubated with secondary antibody (1:3,000; Santa Cruz Biotechnology, Inc; cat. no. sc-2048) at room temperature for $1 \mathrm{~h}$, developed with chemiluminescence ECL reagent (LumiGold; SignaGen Laboratories, Rockville, MD, USA) and exposed to Hyperfilm MP (Beyotime Institute of Biotechnology). The results of each time point in each group were normalized to GAPDH. The relative band intensities of the blots were determined using Adobe Photoshop software (Adobe Photoshop 6.0; Adobe, San Jose, CA, USA).

Apoptosis analysis. ECFCs were harvested, washed with ice-cold PBS, resuspended in binding buffer (500 $\mu \mathrm{l})$, and incubated with propidium iodide (PI; $5 \mu 1$ ) and Annexin V-fluorescein isothiocyanate $(5 \mu \mathrm{l})$ at $4^{\circ} \mathrm{C}$ in the dark for $15 \mathrm{~min}$. The cells were then washed and resuspended in PBS $(500 \mu \mathrm{l})$ and analyzed by flow cytometry (BD Biosciences, San Jose, CA, USA) according to the manufacturer's instructions.

MTT assay. ECFCs were seeded in $96-w e l l$ plates $(4,000$ cells per well). At a series of time points (24, 48, 72 and $96 \mathrm{~h})$ following treatment with TNF- $\alpha$ and/or PACAP, depending on 

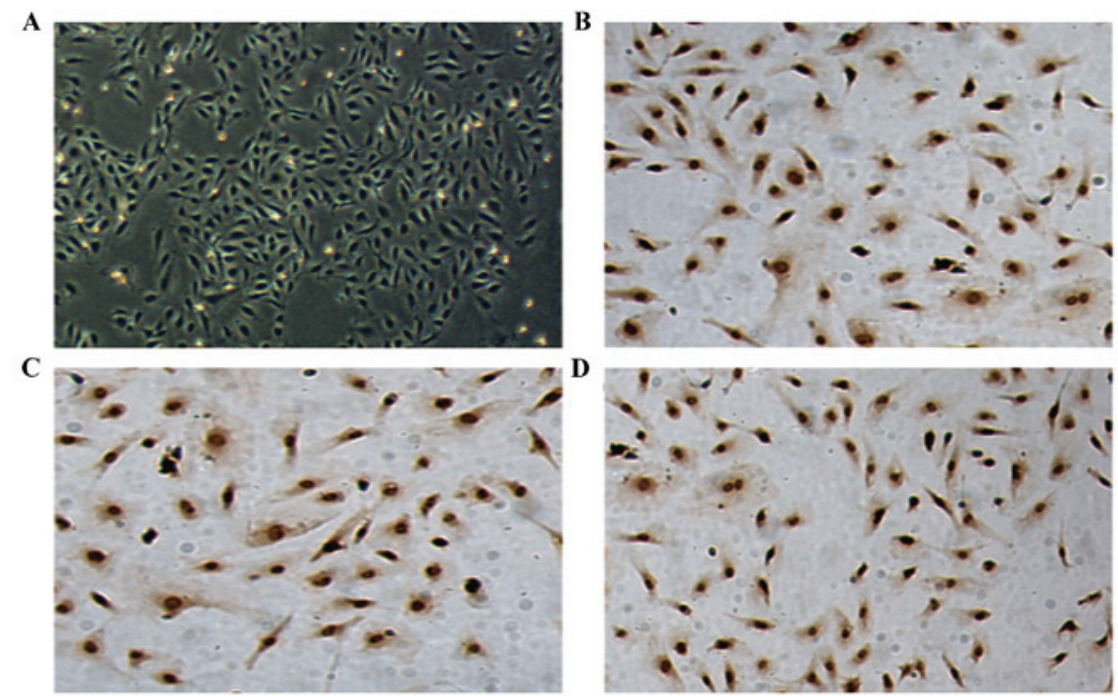

Figure 1. Cell morphology and identification of ECFCs. (A) Bright field microscopic images of cell morphology (magnification, x100). (B) CD31, (C) CD34 and (D) KDR staining as markers of ECFCs (magnification, x100). ECFC, endothelial colony-forming cells; CD, cluster of differentiation.

the group, the cells were incubated with MTT $(5 \mathrm{mg} / \mathrm{ml})$ in PBS for $3 \mathrm{~h}$, and dissolved with $50 \% \mathrm{~N}, \mathrm{~N}$ dimethylformamide (Beyotime Institute of Biotechnology) and 10\% SDS for $3 \mathrm{~h}$ at $37^{\circ} \mathrm{C}$. The optical density was measured at $570 \mathrm{~nm}$. Data are representative of three biological replicates.

Cell cycle analysis. The cell cycle was determined using a Cell Cycle Assay kit from GenMed Scientifics Inc. (Shanghai, China). Briefly, cells were washed twice with PBS and fixed in $80 \%$ ethanol. The fixed cells were washed with PBS, incubated in PI $(50 \mu \mathrm{g} / \mathrm{ml})$ at room temperature for $20 \mathrm{~min}$ and immediately analyzed by flow cytometry according to the manufacturer's instructions.

Statistical analysis. An unpaired Student's t-test was used to evaluate statistical differences between the groups. Data are expressed as the mean \pm standard deviation and $\mathrm{P}<0.05$ was considered to indicate a statistically significant difference. All statistical analyses were performed using SPSS version 19 software (IBM SPSS, Armonk, NY, USA).

\section{Results}

Culture and identification of ECFCs. MNCs were isolated from human UCB and seeded in collagen-coated tissue culture plates in EGM-2MV media. Following $\sim 1$ week of culture, the cells exhibited a paving stone-like morphology (Fig. 1A). Immunocytochemical staining was positive for CD34 (dilution, 1:200), CD31 (dilution, 1:200) and KDR (dilution, 1:400; Fig. 1B-D), identifying the cells as ECFCs.

TNF- $\alpha$ induces ECFC apoptosis. TNF- $\alpha$ significantly increased the cleaved caspase-3 expression level in ECFCs in a concentration-dependent manner (Fig. 2A). In addition, a time course test of caspase-3 expression in ECFCs was performed by treating ECFCs with TNF- $\alpha(20 \mathrm{ng} / \mathrm{ml})$ for 12,24 and $36 \mathrm{~h}$. The results indicated that TNF- $\alpha$ treatment significantly increased the cleaved caspase- 3 expression level in a time-dependent manner (Fig. 2B).
PACAP inhibits TNF- $\alpha$-induced apoptosis of ECFCs. Flow cytometric apoptosis assays indicated that PACAP significantly decreased the number of apoptotic cells in a concentration-dependent manner compared with the TNF- $\alpha$ (20 ng/ml) group. The higher concentrations of PACAP (10 and $100 \mathrm{nM}$ ) induced a statistically significant reduction in apoptotic cell number compared with the TNF- $\alpha(20 \mathrm{ng} / \mathrm{ml})$ group $(\mathrm{P}<0.05$ and $\mathrm{P}<0.01)$. The lower concentration of PACAP $(1 \mathrm{nM})$ reduced the apoptotic cell number, but this was not statistically significant when compared with the TNF- $\alpha$ (20 ng/ml) group ( $\mathrm{P}=0.078$; Fig. 3A).

PACAP restored cell proliferation, which was reduced by $T N F-\alpha$. The viability of ECFCs was evaluated by MTT assay. The proliferation of TNF- $\alpha(20 \mathrm{ng} / \mathrm{ml})$ group was markedly inhibited compared with the control group $(\mathrm{P}<0.01)$. High concentrations of PACAP (10 and $100 \mathrm{nM}$ ) rescued cell proliferation when compared with the TNF- $\alpha(20 \mathrm{ng} / \mathrm{ml})$ group $(\mathrm{P}<0.01)$. No significant differences were observed in cell proliferation between the TNF- $\alpha(20 \mathrm{ng} / \mathrm{ml})$ group and the low concentration PACAP (1 nM) group (Fig. 3B).

Effect of PACAP on cell cycle progression. A dose-dependent effect of PACAP on the cell cycle was observed in the present study. The effect of PACAP on cells appears to be dose-dependent, as a higher dosage of PACAP resulted in a greater number of cells in the G2/M phase. After $48 \mathrm{~h}$ of $100 \mathrm{nM}$ PACAP treatment, cells in the $\mathrm{G} 2 / \mathrm{M}$ population increased from 8.27 to $10.75 \%$ compared with the TNF- $\alpha$ group, whereas the group of cells treated with $10 \mathrm{nM}$ PACAP, the $\mathrm{G} 2 / \mathrm{M}$ population increased to $10.17 \%$. The increase of cell population at the $\mathrm{G} 2 / \mathrm{M}$ phase was accompanied by a decrease of cell population in the G1 phase of the cell cycle (Fig. 3C).

\section{Discussion}

Increased expression levels of inflammation mediators have been implicated in numerous types of vascular disease and these mediators are known to negatively impact endothelial 
A
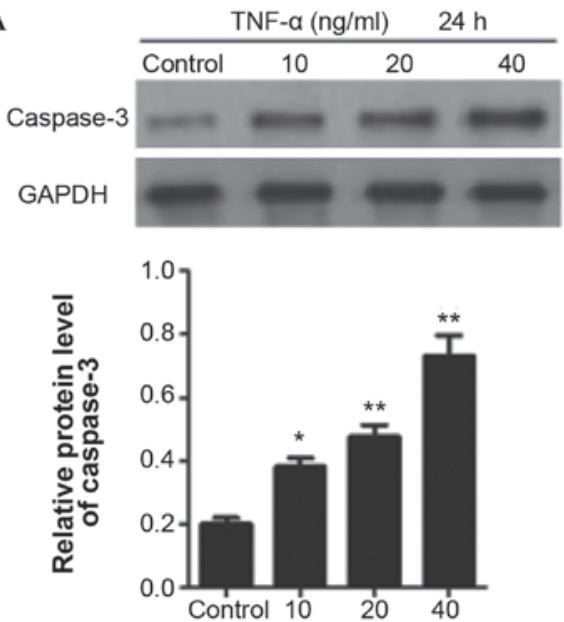

TNF- $\alpha$ concentration $(\mathrm{ng} / \mathrm{ml})$
B
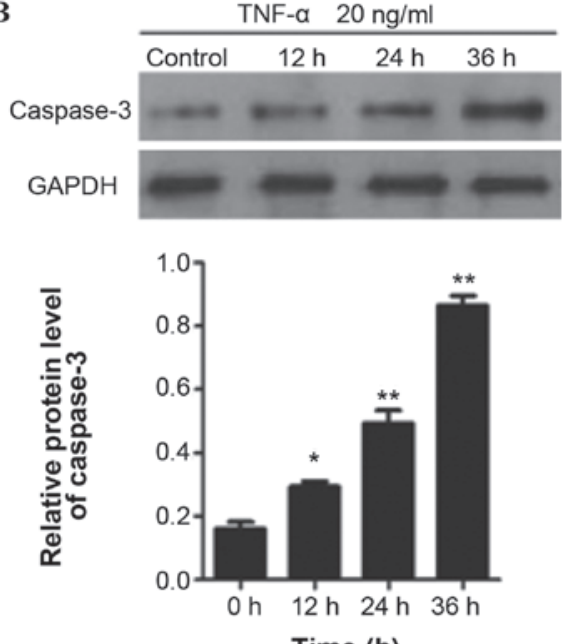

Figure 2. TNF- $\alpha$ increases cleaved caspase-3 expression levels in ECFCs in a concentration- and time-dependent manner. (A) Western blot analysis of cleaved caspase-3 expression levels in ECFCs treated with TNF- $\alpha$ at concentrations of 10, 20 and $40 \mathrm{ng} / \mathrm{ml}$ for $24 \mathrm{~h}$. (B) Western blot analysis of cleaved caspase-3 levels in ECFCs treated with TNF- $\alpha(20 \mathrm{ng} / \mathrm{ml})$ for 12,24 and $36 \mathrm{~h}$. Values in the bar charts are presented as means \pm standard deviation. ${ }^{*} \mathrm{P}<0.05$ and ${ }^{* *} \mathrm{P}<0.01$ vs. Control. TNF- $\alpha$, tumor necrosis factor- $\alpha$; ECFC, endothelial colony-forming cell.

A

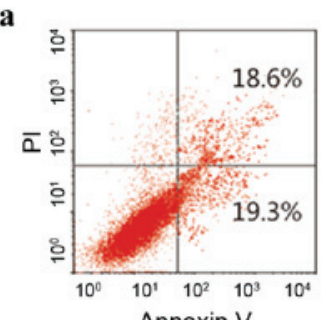

c

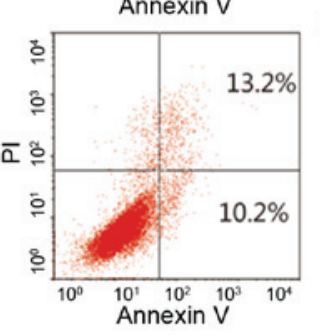

b

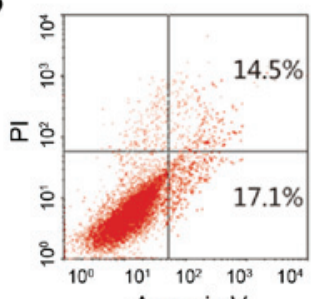

d

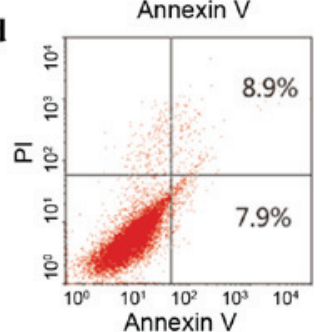

B

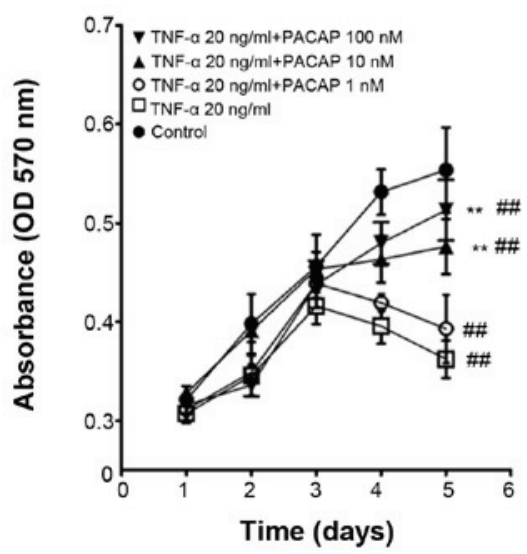

e

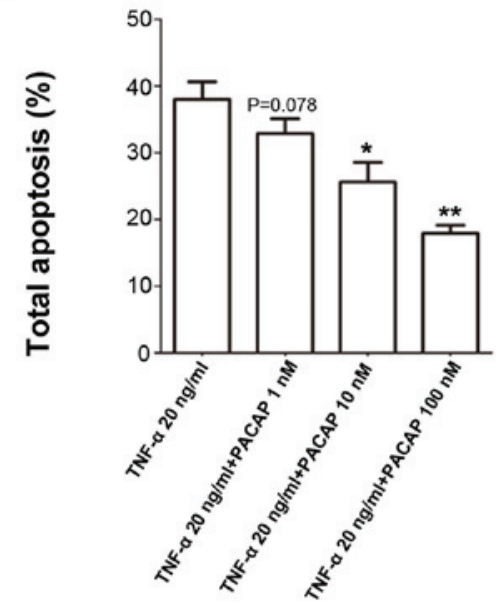

C

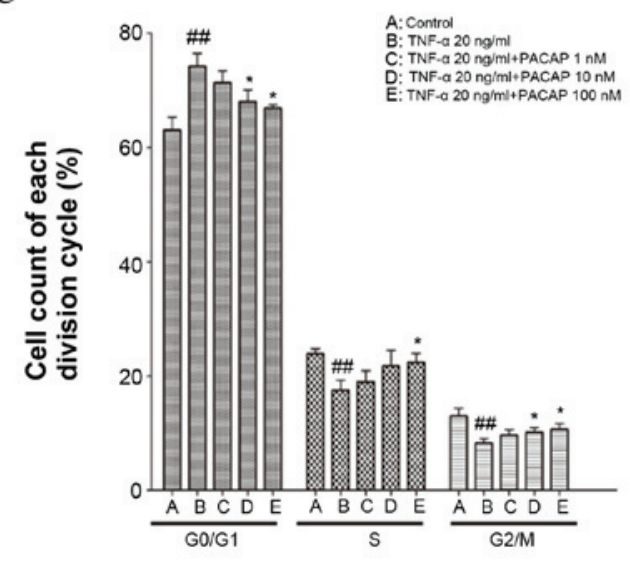

Figure 3. PACAP restores TNF- $\alpha$-induced apoptosis in ECFCs. (A) Effect of TNF- $\alpha$ and PACAP on apoptosis of ECFCs. The cell populations in early and late apoptosis were determined using flow cytometry: (Aa) $20 \mathrm{ng} / \mathrm{ml} \mathrm{TNF}-\alpha$; (Ab) $20 \mathrm{ng} / \mathrm{ml} \mathrm{TNF-} \alpha+1 \mathrm{nM}$ PACAP; (Ac) $20 \mathrm{ng} / \mathrm{ml}$ TNF- $\alpha+10 \mathrm{nM}$ PACAP; (Ad) $20 \mathrm{ng} / \mathrm{ml}$ TNF- $\alpha+100 \mathrm{nM}$ PACAP; (Ae) Bar chart of ECFC apoptosis. (B) Cell proliferation was evaluated by MTT assay. PACAP partially restored proliferation of TNF- $\alpha$-treated ECFCs. (C) Proportion of cells in each cell cycle phase determined by flow cytometry. ${ }^{\# \#} \mathrm{P}<0.01$ vs. Control group; ${ }^{*} \mathrm{P}<0.05$ and ${ }^{* * *} \mathrm{P}<0.01$ vs. $20 \mathrm{ng} / \mathrm{ml}$ TNF- $\alpha$ group. PACAP, pituitary adenylate cyclase-activating polypeptide; TNF- $\alpha$, tumor necrosis factor- $\alpha$; ECFC, endothelial colony-forming cell; PI, propidium iodide. 
cell function in atherosclerosis. Cytoprotective agents present as a promising preventative therapeutic strategy for these conditions, as they negate the apoptotic effects of inflammation. During the pathological progression of atherosclerosis, monocytes and T-lymphocytes are recruited to blood vessel walls and release chemokines, such as monocyte chemoattractant protein-1, TNF- $\alpha$ and IL-6, which are involved in maintaining the inflammatory process. ECFCs are recruited from the bone marrow to these sites of inflammatory signals. Previous studies indicated that acute exposure to low concentrations of TNF- $\alpha$ increases the adhesive properties of ECFCs to vascular endothelial cells (19), although chronic inflammatory stimulation induces ECFC apoptosis $(26,27)$.

PACAP has been shown to limit the effects of chronic inflammation in rheumatoid arthritis and osteoarthritis $(28,29)$. Furthermore, there is strong evidence that PACAP is involved in repair of nerve injury and damage induced by inflammation and oxidative stress (30-32). In addition, our previous studies demonstrated a role for PACAP in atherosclerosis in rabbits and identified receptors for PACAP in cardiovascular tissue (33-35). As a powerful stimulator of inflammation, TNF- $\alpha$ has been reported to induce apoptosis and senescence of ECFCs or other stem cells in vitro and in vivo (36-40); however, to the best of our knowledge, no previous studies have linked PACAP to attenuation of TNF- $\alpha$-induced apoptosis in ECFCs. Caspase- 3 is activated in the apoptotic cell by extrinsic and intrinsic signaling pathways (41). A positive correlation was identified between TNF- $\alpha$ and cleaved caspase-3 expression levels in ECFCs in the present study, indicating that TNF- $\alpha$-mediated inflammation induced ECFC apoptosis. Furthermore, PACAP was shown to exert a direct anti-apoptotic effect on ECFCs treated with TNF- $\alpha$ and enhance proliferation of ECFCs that are inhibited by $\mathrm{TNF}-\alpha$. It has been reported that low concentrations of PACAP cross the blood-brain barrier and may stimulate neurons directly, as well as stimulate astrocytes and microglia to secrete neuroprotective factors (42). During the process of cytoprotection, PACAP may regulate the dynamic balance between the growth factor-activated extracellular signal-regulated kinases and stress-activated c-Jun N-terminal kinases-p38 signaling pathways in neuronal systems (43). However, the anti-apoptosis mechanism of PACAP has not yet been elucidated in ECFCs. Further studies are required to identify the molecular pathways mediating the effects of PACAP and identify the PACAP receptors in ECFCs.

In conclusion, the present results indicate that TNF- $\alpha$ induced apoptosis in ECFCs in a concentration- and time-dependent manner; however, PACAP partially blocks the negative effects of prolonged TNF- $\alpha$ exposure, including ECFC apoptosis, growth inhibition and cell cycle distribution, indicating its therapeutic potential for the treatment of circulatory diseases.

\section{Acknowledgements}

The current study was supported by the Key Subject Construction of the First Affiliated Hospital of Jinan University (Guangzhou, China; grant no. 2010-4).

\section{References}

1. Asahara T: Cell therapy and gene therapy using endothelial progenitor cells for vascular regeneration. Handb Exp Pharmacol 180: 181-194, 2007.

2. Ingram DA, Mead LE, Tanaka H, Meade V, Fenoglio A, Mortell K, Pollok K, Ferkowicz MJ, Gilley D and Yoder MC: Identification of a novel hierarchy of endothelial progenitor cells using human peripheral and umbilical cord blood. Blood 104: 2752-2760, 2004.

3. Steinmetz M,Nickenig G and Werner N: Endothelial-regenerating cells: An expanding universe. Hypertension 55: 593-599, 2010.

4. Blue EK, DiGiuseppe R, Derr-Yellin E, Acosta JC, Pay SL, Hanenberg H, Schellinger MM, Quinney SK, Mund JA, Case J, et al: Gestational diabetes induces alterations in the function of neonatal endothelial colony-forming cells. Pediatr Res 75: 266-272, 2014.

5. Ingram DA, Lien IZ, Mead LE, Estes M, Prater DN, Derr-Yellin E, DiMeglio LA and Haneline LS: In vitro hyperglycemia or a diabetic intrauterine environment reduces neonatal endothelial colony-forming cell numbers and function. Diabetes 57: 724-731, 2008.

6. Ikutomi M, Sahara M, Nakajima T, Minami Y, Morita T, Hirata Y, Komuro I, Nakamura F and Sata M: Diverse contribution of bone marrow-derived late-outgrowth endothelial progenitor cells to vascular repair under pulmonary arterial hypertension and arterial neointimal formation. J Mol Cell Cardiol 86: 121-135, 2015.

7. Vanhoutte PM: Endothelial dysfunction: The first step toward coronary arteriosclerosis. Circ J 73: 595-601, 2009.

8. Kawamoto A, Gwon HC, Iwaguro H, Yamaguchi JI, Uchida S, Masuda H, Silver M, Ma H, Kearney M, Isner JM, et al: Therapeutic potential of ex vivo expanded endothelial progenitor cells for myocardial ischemia. Circulation 103: 634-637, 2001.

9. Werner L, Deutsch V, Barshack I, Miller H, Keren G and George J: Transfer of endothelial progenitor cells improves myocardial performance in rats with dilated cardiomyopathy induced following experimental myocarditis. J Mol Cell Cardiol 39: 691-697, 2005.

10. Hill JM, Zalos G, Halcox JP, Schenke WH, Waclawiw MA, Quyyumi AA and Finkel T: Circulating endothelial progenitor cells, vascular function, and cardiovascular risk. N Engl J Med 348: 593-600, 2003.

11. Scalone G, De Caterina A, Leone AM, Tritarelli A, Mollo R, Pinnacchio G, D'Amario D, Lanza GA and Crea F: Effect of exercise on circulating endothelial progenitor cells in microvascular angina. Circ J 77: 1777-1782, 2013.

12. Fujita $\mathrm{Y}$ and Asahara T: Evaluation of circulating endothelial progenitor cells in cardiovascular risk. Circ J 75: 2541-2542, 2011.

13. Etemadifar M, Dehghani L, Ganji H, Soleimani R, Talebi M, Eskandari N, Samani FS and Meamar R: Evaluation of the circulating CD34(+), CD309(+), and endothelial progenitor cells in patients with first attack of optic neuritis. Adv Biomed Res 4: 151,2015

14. Duckers HJ, Silber S, de Winter R, den Heijer P, Rensing B, Rau M, Mudra H, Benit E, Verheye S, Wijns W, et al: Circulating endothelial progenitor cells predict angiographic and intravascular ultrasound outcome following percutaneous coronary interventions in the HEALING-II trial: Evaluation of an endothelial progenitor cell capturing stent. EuroIntervention 3: 67-75, 2007.

15. Kaehler J, Osterholz S, Patten M, Koester R and Meinertz T: Cytokines in the pathogenesis of atherosclerosis. Dtsch Med Wochenschr 127: 94-99, 2002 (In German).

16. Takahashi M: Inflammatory cytokines in the pathogenesis of atherosclerosis. Nihon Rinsho 69: 30-33, 2011 (In Japanese).

17. Prisco AR, Prisco MR, Carlson BE and Greene AS: TNF- $\alpha$ increases endothelial progenitor cell adhesion to the endothelium by increasing bond expression and affinity. Am J Physiol Heart Circ Physiol 308: H1368-H1381, 2015.

18. Walsh LJ, Trinchieri G, Waldorf HA, Whitaker D and Murphy GF: Human dermal mast cells contain and release tumor necrosis factor alpha, which induces endothelial leukocyte adhesion molecule 1. Proc Natl Acad Sci USA 88: 4220-4224, 1991.

19. Miyata A, Arimura A, Dahl RR, Minamino N, Uehara A, Jiang L, Culler MD and Coy DH: Isolation of a novel 38 residue-hypothalamic polypeptide which stimulates adenylate cyclase in pituitary cells. Biochem Biophys Res Commun 164: 567-574, 1989. 
20. Heimesaat MM, Dunay IR, Schulze S, Fischer A, Grundmann U, Alutis M, Kühl AA, Tamas A, Toth G, Dunay MP, et al: Pituitary adenylate cyclase-activating polypeptide ameliorates experimental acute ileitis and extra-intestinal sequelae. PLoS One 9: e108389, 2014

21. Vaudry D, Falluel-Morel A, Bourgault S, Basille M, Burel D, Wurtz O, Fournier A, Chow BKC, Hashimoto H, Galas L, et al: Pituitary adenylate cyclase-activating polypeptide and its receptors: 20 years after the discovery. Pharmacol Rev 61: 283-357, 2009.

22. Giunta S, Castorina A, Adorno A, Mazzone V, Carnazza ML and D'Agata V: PACAP and VIP affect NF1 expression in rat malignant peripheral nerve sheath tumor (MPNST) cells. Neuropeptides 44: 45-51, 2010.

23. Castorina A, Waschek JA, Marzagalli R, Cardile V and Drago F: PACAP interacts with PAC1 receptors to induce tissue plasminogen activator (tPA) expression and activity in schwann cell-like cultures. PLoS One 10: e0117799, 2015.

24. Tan YV, Abad C, Lopez R, Dong H, Liu S, Lee A, Gomariz RP, Leceta $J$ and Waschek JA: Pituitary adenylyl cyclase-activating polypeptide is an intrinsic regulator of Treg abundance and protects against experimental autoimmune encephalomyelitis. Proc Natl Acad Sci USA 106: 2012-2017, 2009.

25. Armstrong BD, Abad C, Chhith S, Cheung-Lau G, Hajji OE, Nobuta $\mathrm{H}$ and Waschek JA: Impaired nerve regeneration and enhanced neuroinflammatory response in mice lacking pituitary adenylyl cyclase activating peptide. Neuroscience 151: 63-73, 2008

26. Du G, Song Y, Zhang T, Ma L, Bian N, Chen X, Feng J, Chang Q and Li Z: Simvastatin attenuates TNF- $\alpha$ induced apoptosis in endothelial progenitor cells via the upregulation of SIRT1. Int J Mol Med 34: 177-182, 2014.

27. Sasi SP, Song J, Enderling H, Yan X and Goukassian DA: TNF- $\alpha$ and IL- $1 \alpha$ but not MCP 1 and Rantes increase significantly the formation of $\mathrm{p}-\mathrm{H} 2 \mathrm{AX}$ foci in naive BM-derived TNFR1/p55KO EPCs. J Radiat Res 55 (Suppl 1): i122-i123, 2014.

28. Botz B, Bölcskei K, Kereskai L, Kovács M, Németh T, Szigeti K, Horváth I, Máthé D, Kovács N, Hashimoto H, et al: Differential regulatory role of pituitary adenylate cyclase-activating polypeptide in the serum-transfer arthritis model. Arthritis Rheumatol 66: 2739-2750, 2014.

29. Juhász T, Helgadottir SL, Tamás A, Reglődi D and Zákány R: PACAP and VIP signaling in chondrogenesis and osteogenesis. Peptides 66: 51-57, 2015.

30. Yu R, Xie S, Chen J, Zhang L and Dai Y: The effects of PACAP and related peptides on leptin, soluble leptin receptor and resistin in normal condition and LPS-induced inflammation. Peptides 30: $1456-1459,2009$.

31. Tsumuraya T, Ohtaki H, Song D, Sato A, Watanabe J, Hiraizumi Y, Nakamachi T, Xu Z, Dohi K, Hashimoto H, et al: Human mesenchymal stem/stromal cells suppress spinal inflammation in mice with contribution of pituitary adenylate cyclase-activating polypeptide (PACAP). J Neuroinflammation 12: 35, 2015.
32. Waschek JA: VIP and PACAP: Neuropeptide modulators of CNS inflammation, injury, and repair. Br J Pharmacol 169: 512-523, 2013.

33. Chang Q, Li ZC and Deng Y: The distribution of pacap receptor on the cardiovascular tissues and cells. J Clin Cardiol 18: 329-331, 2002.

34. Chang Q, Zhang L, Tang HL, Huang HM and Zi Cheng LI: Effects of pituitary adenylate cyclase activating polypeptide on cardiac remodeling in coronary atherosclerotic rabbits. Chin J Pathophysiology 23: 529-532, 2007.

35. Cheng ZL: The changes of collagen and mmp 2 in atherosclerotic rabbit aorta and effect of pacap. Guangdong Med 29: 1107-1109, 2008.

36. Qiao J, Qi K, Chu P, Mi H, Yang N, Yao H, Xia Y, Li Z, Xu K and Zeng L: Infusion of endothelial progenitor cells ameliorates liver injury in mice after haematopoietic stem cell transplantation. Liver Int 35: 2611-2620, 2015.

37. Martini G, Biscaro F, Boscaro E, Calabrese F, Lunardi F, Facco M, Agostini C, Zulian F and Fadini GP: Reduced levels of circulating progenitor cells in juvenile idiopathic arthritis are counteracted by anti TNF- $\alpha$ therapy. BMC Musculoskelet Disord 16: 103, 2015.

38. Wang XX, Yang JX, Pan YY and Zhang YF: Protective effects of tanshinone IIA on endothelial progenitor cells injured by tumor necrosis factor- $\alpha$. Mol Med Rep 12: 4055-4062, 2015.

39. Cao Q, Wang Y, Huang L, Wang F and Chen S: TNF receptor-associated factor 6 (TRAF6) mediates the angiotensin-induced non-canonical TGF- $\beta$ pathway activation of c-kit(+) cardiac stem cells. Am J Transl Res 7: 2233-2243, 2015.

40. Liao L, Su X, Yang X, Hu C, Li B, Lv Y, Shuai Y, Jing H, Deng Z and Jin Y: TNF- $\alpha$ Inhibits FoxO1 by Upregulating miR-705 to Aggravate Oxidative Damage in Bone Marrow-Derived Mesenchymal Stem Cells during Osteoporosis. Stem Cells 34: 1054-1067, 2016.

41. Salvesen GS: Caspases: Opening the boxes and interpreting the arrows. Cell Death Differ 9: 3-5, 2002.

42. Shioda S, Ohtaki H, Nakamachi T, Dohi K, Watanabe J, Nakajo S, Arata S, Kitamura S, Okuda H, Takenoya F, et al: Pleiotropic functions of PACAP in the CNS: Neuroprotection and neurodevelopment. Ann N Y Acad Sci 1070: 550-560, 2006.

43. May V, Lutz E, MacKenzie C, Schutz KC, Dozark K and Braas KM: Pituitary adenylate cyclase-activating polypeptide (PACAP)/PAC1HOP1 receptor activation coordinates multiple neurotrophic signaling pathways: Akt activation through phosphatidylinositol 3-kinase gamma and vesicle endocytosis for neuronal survival. J Biol Chem 285: 9749-9761, 2010. 